\title{
KAS TAHTMA TAHAB ABIVERBIKS? ${ }^{1}$
}

\section{Külli Habicht, Pille Penjam ja Ilona Tragel Tartu Ülikool}

Kokkuvõte. Artiklis käsitletakse eesti keele polüseemse verbi tahtma semantilist ja morfosüntaktilist arengut 16. sajandist kuni tänapäevani. Materjal pärineb põhiosas eesti kirjakeele korpustest. Grammatisatsiooniteooria taustal vaadeldakse astmeid, mille see verb on eesti keeles läbinud alates täistähenduslikust kasutusest kuni kõrgel grammatisatsiooniastmel modaalsete ja postmodaalsete konstruktsioonideni välja. Käsitluses keskendutakse eri tüüpi infinitiivitarindite koosseisus esinevale tahtma-verbile, millega vormistatakse muuhulgas agendi tahet ja kavatsust, osalejasisest võimalikkust ja vajalikkust, episteemilist modaalsust ning ka postmodaalseid tähendusi (avertiivsus/proksimatiivsus, habituaalsus) kandvaid konstruktsioone. Vana kirjakeele perioodil (kuni 18. sajandini) on kasutusel olnud ka saksamõjulisi tahtma-tuleviku konstruktsioone. Artiklis visandatakse tahtmaverbi võimalik grammatiseerumistee ning jõutakse järelduseni, et tahtma on kindlates konstruktsioonides kujunenud abiverbiks, kuid grammatiseerunud kasutuste kõrval on keeles säilinud ka oletatav algne leksikaalne 'soovimise' tähendus.

Märksõnad: tahtma, modaalkonstruktsioonid, grammatiseerumine, eesti kirjakeel

\section{Sissejuhatus}

Artiklis võtame vaatluse alla osakese sellest teemavaldkonnast, millega on aastate jooksul põhjalikult tegelnud ka hea kolleeg professor Helle Metslang, kellele siinse artikli pühendame. Käsitleme eesti polüseemse verbi tahtma semantilist ja morfosüntaktilist kujunemist alates 16 . sajandist kuni tänapäevani.

${ }^{1}$ Artikkel on valminud ETFi grantide 7464 (Pille Penjam, Ilona Tragel) ja 7552 (Külli Habicht) toel. 
Selle verbi areng on kulgenud täistähenduslikust grammatilise suunas ning läbinud astmeid, millest osa on tänapäevaks keelest taandunud. tahtma-verbiga vormistatud grammatilised konstruktsioonid on saanud kirjakeele algusperioodil mõjutusi ka saksa keelest. Eesti keele edaspidise, iseseisvama kujunemise käigus pole tahtma end siiski kuigi palju mõjutada lasknud, sest näiteks regulaarset tahtma-tulevikku eesti keeles ei ole. Küll aga on üsna selgelt eristatavad mõningad osalejakesksest (juur)modaalsusest lähtuvad modaaltähendused kuni episteemilise modaalsuseni välja. Viimasest omakorda lähtuvad postmodaalsed kasutused, nagu avertiiv/proksimatiiv ja habituaal.

\subsection{Meetod ja eesmärgid}

Siinne käsitlus lähtub grammatisatsiooni üldistest põhimõtetest, mille kohaselt grammatiseeruv üksus muutub tähenduselt abstraktsemaks, morfosüntaktiliselt vähem iseseisvaks ning võib foneetiliselt lüheneda (Heine jt 1991, Traugott ja Heine 1991, Hopper ja Traugott 1993, Heine ja Kuteva 2002 ning 2007; eesti keeles Metslang 2002 ja 2006). Niisiis vaatleme tahtma-verbi tähenduses toimunud muutusi konkreetsemast abstraktsema suunas, jälgime verbi morfosüntaktiliste omaduste muutumist, sh iseseisvuse vähenemist ja võimalikku abiverbistumist ${ }^{2}$ (vt ka Bybee jt 1994, Kuteva 1999, Heine ja Kuteva 2006) ning visandame kokkuvõttes arvatava grammatiseerumisahela. Grammatiseerumisastme üle otsustamisel on aluseks ennekõike Heine ja Kuteva (2002) grammatisatsioonileksikonis esitatud tüüpiliste arenguteede kirjeldused. Modaaltähenduste grammatiseerumist käsitleme järgmisest universaalsest arenguahelast lähtudes: leksikaalne tähendus $>$ osalejasisene vajalikkus/võimalikkus $>$ osalejaväline vajalikkus/võimalikkus $>$ episteemiline vajalikkus/võimalikkus > postmodaalsed tähendused (Auwera ja Plungian 1998, Bybee jt 1994: 199).

${ }^{2}$ Abiverbina on siinses käsitluses mõistetud verbi, mis esineb verbifraasis koos infinitiivses vormis leksikaalse verbiga ja väljendab mõnd spetsiifilist grammatilist tähendust (vt ka Heine ja Kuteva 2006: 327). 
Püüame materjali analüüsi põhjal näidata, et sellistes rikka morfoloogiaga keeltes nagu eesti keel toimub ühelt poolt erivormiliste konstruktsioonide sisuline eristumine ning grammatiseerumine, samal ajal kui konstruktsioonis osaleva abiverbistuva üksuse teised tähendused enamasti ei kao, vaid säilivad üha sagedamaks muutuvate grammatiliste tähenduste kõrval (vt ka Hopper ja Traugott 1993: 3, Kuteva 2001: 5). Sama tähenduse edasiandmiseks võib kasutusel olla ka semantiliselt sarnaseid, kuid vormilt erinevaid konstruktsioone. Niisiis on grammatiseerumise teed jälgitavad ka sünkroonses keelepildis, st samast keeleüksusest elab keeles korraga suhteliselt skemaatilise tähendusega variant (mille skemaatilisust, üldisust ehk grammatilisust saab mõõta morfosüntaktilise iseseisvuse vähesusega) (vt nt Heine ja Kuteva 2006: 80-82; 89-92) ja iseseisva tähendusega keeleüksus, mis võib säilitada algse leksikaalse tähenduse.

\subsection{Materjal}

Siinse käsitluse lähtematerjal pärineb põhiosas eesti kirjakeele korpustest: vana kirjakeele korpusest (edaspidi näidete järel lühend VAKK) ja 1890.-1990. aastate valikkorpusest (lühend TÜKK). Spetsiaalselt siinse uurimuse tarbeks loodud ja statistilisi andmeid pakkuv väiksem alamkorpus hõlmab Tartu Ülikooli eesti kirjakeele korpuse tekste 1890., 1930., 1970. ja 1990. aastatest. Näitelauseid on registreeritud ka suulisest keelekasutusest, ilmunud teadusartiklitest ja eri Interneti-allikatest. Mõnel juhul on sobiv näitelause loodud ka artikli autorite enda keelekompetentsusele tuginedes. Vana kirjakeele korpuse lausetele on lisatud tänapäevane „tõlge“ ainult juhtudel, kui arhailise leksika või vormistiku kasutamise tõttu ei pruugi lause tänapäeva lugejale üheselt mõistetav olla.

Viited on lisatud sulgudes näitelausete järel ja need osutavad kõigepealt korpusele, kust vastav näide pärineb; seejärel on VAKKi näidete juures välja toodud teksti autori nimi ja ilmumisaasta, TÜKKi näidete puhul alamkorpuse lühend (aja - ajakirjandustekstid, ilu - ilukirjandustekstid, $U M$ - uus meedia) ja kümnend, millest näide pärineb. Muude Interneti-allikate korral 
on esitatud terviklik võrguaadress. Ilma viiteta näited on autorite enda loodud.

\subsection{Artikli ülesehitus}

Artikli esimene osa on sissejuhatus, kus piiritletakse uurimuse eesmärgid ja teoreetiline taust ning põhjendatakse teemavalikut. Teises osas tutvustatakse lühidalt tahtma-verbi päritolu ja tähendusnüansse ning iseloomustatakse üldtüpoloogiliselt tahtma-verbiga edastatavat mõistesisu. Kolmandas osas võetakse vaatluse alla põhilised, sagedasemad, kuid vähem grammatilised konstruktsioonitüübid, mida tahtma-verb eesti keeles vormistab. Neljas osa keskendub modaaltähenduste eritlemisele ja nende omavaheliste seoste väljaselgitamisele, viies osa tulevikukonstruktsioonidele ning kuues osa postmodaalsetele tähendustele. Põhieesmärgiks on välja selgitada tahtma-verbi sellised kasutused, milles mingi tähenduse väljendamiseks on kinnistunud kindel konstruktsioon. Kokkuvõttes tuuakse välja mõningad üldistused ja järeldused tahtma-verbi arengu ning tähenduste omavaheliste seoste kohta grammatisatsiooni kulgu silmas pidades. Püütakse vastata küsimusele, mis selle verbi semantika ja morfosüntaksi arengus on teinud võimalikuks modaal- jt grammatiliste tähenduste tekkimise.

\section{Taust}

\section{1. tahtma-verbi päritolu ja tähendus}

tahtma-verbil on etümoloogilisi vasteid kõikides läänemeresoome keeltes, nt karjala tahtuo, lüüdi tahtoda, vadja ja soome tahtoa, liivi $t \bar{o}$ 'dõ. Võimalikuks vasteks on peetud ka saami duostot 'haarama, kinni või vastu võtma; takistama, tõrjuma'. (Mägiste 2000: 3045-3046 ja Häkkinen 2005: 1254) Verbi algne päritolu on siiski ebaselge. (Häkkinen 2005: 1254)

Tahtmine kuulub intrasubjektiivsete mõistete valdkonda, väljendades soovi (ingl desire) ja/või tahet (ingl volition). 
tahtma on oma algselt tähenduselt olnud tõenäoliselt ka eesti keeles suhteliselt neutraalne agendi soovi/tahet väljendav verb, mis ei täpsusta kuigi selgelt tahtmise/soovimise viisi, olles sellisena sobiv kandidaat veelgi üldisemate mõistete väljendamiseks ja/või tähendusülekanneteks.

Tänapäeva eesti kirjakeeles on verbil tahtma eristatud järgmisi põhitähendusi: 1) soovima, püüdma, vajadust tundma midagi saada, teha, saavutada; püüd(le)ma (Lapsed tahavad palju liikuda.); 2) tungivalt, vältimatult vajama (Põld tahab künda, kartul tahab võtta.); 3) osutus millelegi mittesoovitavale, mis on peaaegu juhtumas või oleks võinud juhtuda = 'kippuma', 'pidama' (Poiss tahab naerust nõrkeda.); 4) eitavas vormis osutus millegi toimumise takistatusele või millegi toimumiseks eelduse puudumisele (Uni ei taha tulla.); 5) da-infinitiivis koos olemaverbiga osutus sellele, et miski pretendeerib millelegi, selleks vajalikke eeldusi omamata (Film tahtis naljakas olla.); 6) esinemine leksikaliseerunud ja idiomatiseerunud ühendites (Tee mis tahad. See tuleb tahes või tahtmata ära teha.) (EKSS 2009: 596-597)

\subsection{Tüpoloogiline taust}

Mõiste TAHTMA grammatiseerumise teid on üsna palju uuritud (ingl will, sks wollen jne) (vt Heine ja Kuteva 2002: 309-313). Maailma keelte grammatiseerumise leksikoni andmetel on TAHTMA-tähendusega verbidel maailma keeltes järgmised grammatilised kasutused:

(1) avertiivne, tekib TAHTMA-verbide minevikuvormidest, nt bulgraaria keele štjax (< 'tahtis') 'peaaegu';

(2) tulevik, nt inglise will; ladina volere baasil arenenud futuurumimarker romaani keeltes;

(3) proksimatiiv, nt ungari akar 'soovima, tahtma' > proksimatiivi marker. (Heine ja Kuteva 2002: 309-313)

Seejuures ei ole avertiivi ja proksimatiivi tähenduserinevus leksikoni näidete põhjal päris selge, kuigi avertiivi tekkimise allikad on piiratud verbi minevikuliste kasutustega. Seda verbi tahtma postmodaalset tähendust ning avertiivi/proksimatiivi 
tõlgendust käsitleme osas 5.2. Muuhulgas ka verbi tahtma näitel on avertiivi ja proksimatiivi erinevusi ja eristatavust lahanud Erelt ja Metslang (2009), sellest samuti täpsemalt tagapool (jaotis 5.2).

tahtma-tuleviku universaalseks lähtetähenduseks on 'tahe', millega paratamatult seondub 'valmidus'. Oluline tähenduslik etapp tuleviku kujunemisel on ka 'kavatsus', millest omakorda lähtub 'ennustuse' tähendus (Bybee jt 1994: 254-255).

Helle Metslang on kirjeldanud tahtma-verbi grammatilist kasutust motiveerinud tähendusülekande tüüpi, mis tugineb nihkele ühe järeldussuhte piires ja mida iseloomustab osalejakeskse modaalsuse, muutumise ja tegevuse alguse käsitamine futuurumina. Seda ilmestab reanalüüsiahel (Metslang 1994: 544):

1) ma tahan midagi teha;

2) ma tahan midagi teha, järelikult see, mida ma ehk teen, toimub tulevikus;

3) ma tahan midagi teha, järelikult ma teengi seda;

4) see, et ma tahan midagi teha, tähendab tegelikult, et ma tulevikus teengi seda.

Ehkki tulevikku väljendavat grammatilist tahtma-konstruktsiooni tänapäeva eesti keeles pole, on eeldused selle kujunemiseks olemas ja tahtma-tuleviku võimalikkusele osutab seegi, et tõlkemõjulise kirjakeele perioodil on see grammatilise kopeerimise tulemusena eestikeelsetes tekstides kasutust leidnud.

Eesti keeles on verbi tahtma eri tahke uurinud veel Habicht (2001: 163-174), Tragel (2003: 45-46), Penjam (2008: 75-82; $92 ; 215-219)$. Siinses artiklis esitame oma varasemate tulemuste edasiarendusi.

\section{Tähendused ja konstruktsioonid}

Järgnevates jaotistes kirjeldatakse tahtma-verbi konstruktsioone eesti kirjakeeles. Lisaks konstruktsioonide ehitusele pakub huvi ka nende suhteline esinemissagedus. Iga konstruktsiooni puhul on kõigepealt tutvustatud selle ehitust, tüüpilisi kasutuskontekste ja eripära mitmesuguste 16.-21. sajandi tekstide põhjal eesti keele esimestest kirjalikest allikatest kuni tänapäeva uue meedia 
alamkorpuseni, seejärel aga esitatud konstruktsiooni esinemise sagedusandmed väiksema alamkorpuse põhjal, mis hõlmab Tartu Ülikooli eesti kirjakeele korpuse tekste 1890., 1930., 1970. ja 1990. aastatest.

Statistiliseks analüüsiks kasutatud valikkorpus on koostatud järgmiselt: esmalt on iga kümnendi alamkorpusest valitud 300 juhuslikku lauset, mis andsid positiivse päringu otsisõnele [Tt]ah[ate] (lisaks korpuse otsimootori pakutavatele juhuvalimi koostamise võimalustele kasutasime seejuures tabelitöötlusprogrammi MS Excel 2002 juhuslike arvude generaatorit). Saadud valimist on käsitsi eemaldatud laused, mis ei sisaldanud verbi tahtma, samuti need laused, kus tahtma-verb esines leksikaliseerununa (eeskätt ühendis tahes-tahtmata) või kus konstruktsioonist puudusid väljajätu tõttu tahtma-verbi laiendid, nt

(1) ILU1990 Lõpuks ütles treener: .. Maksa siis, Samuel, kui tahetakse! (TÜKK, ilu 1990)

Sel moel on saadud tahtma-konstruktsioonide korpus, mis sisaldab 244 näidet 1890. aastatest, 213 näidet 1930. aastatest, 207 näidet 1970. aastatest ning 183 näidet 1990. aastatest.

\subsection{Agendi tahet (soovi) väljendavad konstruktsioonid}

3.1.1. Käändsõnalise objektiga tahtekonstruktsioon: TAHTJA (nominatiiv) + tahtma (vormipiiranguid ei ole) + TAHETAV (partitiiv)

Selliseid näiteid, kus tahtma-verb väljendab grammatilise subjekti vormis agendi soovi mingi nominaalse objekti järele, leidub juba 16. sajandi kirjakeeles, ehkki vanimatele tekstidele iseloomulikult varieerub neis tekstides veel objektikäände valik, nt

(2) Sina ei peat tachtma oma laehembe kotta, sullan, tuttrikut, döbbrat, nink kik mea tema peralt om. (VAKK, Völcker 1585-1590). 
Ka 20. sajandi tekstides esineb seda tüüpi näiteid rohkelt, nt

(3) Ammu oli ta tahtnud enesele mingit ülesannet pagulaseestlaste ühiskonnas .. (TÜKK, ilu 1990)

TAHTJA on selles konstruktsioonis elus, oma soove kontrolliv agent, TAHETAV on tavaliselt ese, ehkki mõeldavad on ka elusad objektid või abstraktsed nähtused, vt näide 2, 4, 5):

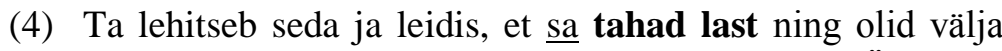
kirjutanud kusagilt raamatust: Liebe ist: Geben. (TÜKK, ilu 1930)

(5) Osa sellest tuleb ettekande kontosse kirjutada, mis oli liiga üheülbaline, oleks tahtnud rohkem dünaamilisi gradatsioone. (TÜKK, aja 1970)

Tinglikult võib elusa tegutsejana käsitada ka asutusi, ühendusi ja organisatsioone, kes käituvad lauses tahtelise agendina, nt

(6) Vanad parteid kaotasid liikmeskonda, uued aga tahtsid ainult hääli ja sageli olid valimistel edukalt esinenud erakonnad liikmete arvult tõelised kääbused. (TÜKK, aja 1990)

Üksikutel juhtudel võib TAHTJA olla ka mõni loom või personifitseeritud elutu objekt, nt

(7) Jaaguar ei taha olla puuris, seda oleme kõik näinud, ehkki puuriga kohanenud jaaguare võiks mu oponent hulgi välja pakkuda. (TÜKK, ilu 1990)

(8) Siis kui mul oli Win98 ei saand mingist rekordist juttugi olla, ikka päevas kord-kaks tahtis restarti .. (http:// forum.planet.ee/showthread.php?t=11718.)

Peaaegu kõikides nominaalse objektiga tahtma-soovlausetes on tegelikult alati mingi verb n-ö juurdemõeldav, nt tahab maja, sulast, ülesannet, last, hääli (saada); oleks tahtnud rohkem 
dünaamilisi gradatsioone (kuulda); ta tahab kooki (sü̈̈a/saadal võtta); Mare tahab uut kampsunit (osta/saada).

Nominaalse objektiga tahtma-soovlausete hulka võib tinglikult paigutada ka mitmeid kivinenud püsiväljendeid, nt

(9) Kurat temaga, las teeb mis tahab .. (TÜKK, ilu 1970)

(10) Ent kuidas sattus Linda siia, mis tahtsid temast sakslased? (TÜKK, ilu 1930)

Nominaalse objektiga tahtma-konstruktsioonide esinemissagedus valikkorpuses oli järgmine: 11 näidet (5\% kõigist tahtmakonstruktsioonidest) 1890 . aastate korpuses, 15 näidet (7\%) 1930. aastate korpuses, 27 näidet (13\%) 1970. aastate korpuses ning 24 näidet (13\%) 1990. aastate korpuses.

\subsection{2. $d a$-infinitiivis objektiga tahtekonstruktsioon:}

TAHTJA (nominatiiv) + tahtma (vormipiiranguid ei ole) + TAHETAV ( $d a$-infinitiiv)

Konstruktsioone, kus tahetavaks objektiks on mingi agendi enda sooritatav tegevus või tema põhjustatud sündmus, võib tõlgendada kui osalejasisest võimalikkust väljendavaid modaalkonstruktsioone (vt ka jaotis 4.2). Need konstruktsioonid on ilmselt kõige prototüüpsemad tänapäeva eesti kirjakeeles esinevad taht$m a$-konstruktsioonid, kuid nende näiteid võib leida ka vanast kirjakeelest. Seejuures on vana kirjakeele puhul omapärane see, et mitmetes 17. sajandi tekstides, kõige ulatuslikumalt kindlasti Heinrich Stahlil, varieerub tahtma-konstruktsioonides (aga ka teistes infinitiivikonstruktsioonides) $m a$ - ja $d a$-infinitiivi kasutamine. Sagedasem on Stahlil tänapäeva keele seisukohalt ebaootuspärane $m a$-infinitiiv, $\mathrm{nt}$

(11) Jummal tahap ommat usckolisset öigke te pehl sahtma. (VAKK, Stahl 1641) 'Jumal tahab oma usklikud õige tee peale saata.'

(12) .. pallusit nem at temma ninck pajatasit: Jeh meije jures/ sest se öcht tahap tulla/ ninck se pehwlick on alla minnut. (VAKK, Stahl 1641) 'Palusid nad teda ja rääkisid: „Jää 
meie juurde, sest õhtu tahab tulla (= on tulemas) ja päike on loojunud."'

Stahli teostes on tahtma-konstruktsioonides kasutatud $m a-$ ja $d a$-infinitiivi vormide suhe $178: 1180$ ehk ligikaudu $1: 7 \mathrm{ma}$ infinitiivi kasuks (vt Habicht 2001: 170). Sellest vormilisest erinevusest hoolimata ei ole Stahli eri infinitiividega vormistatud dünaamilismodaalsetel, episteemilistel ja tulevikukonstruktsioonidel funktsionaalset erinevust. $d a$ - ja $m a$-infinitiivi varieerumine on jälgitav veel kuni 1715. a uue testamendini, kus tahtmakonstruktsioonis leidub üksikuid $m a$-infinitiivi näiteid, nt

(13) Ja temma tahhab neid wallitsema Raud-witsaga/ neid peab otsego sawwised Astjad pihhuks pörrutama/ .. (VAKK, UT 1715) 'Ja tema tahab neid valitseda raudvitsaga, neid peab otsekui savinõusid purustama..'

Ka agendikeskse tähendusega infinitiivikonstruktsioonis on TAHTJA üldjuhul elus, oma soove kontrolliv agent, nt

(14) Sina oled mulle raske tõotusega truuks lubanud jääda, oota, ka mina tahan ühe weikse tõotuse teha. (TÜKK, ilu 1890)

(15) Iga näitleja tahab luua lõpetatud ja tervikliku kuju ja me oleme alati tema töö lõpuleviiduse ja teistest eraldatuse meelsasti vastu võtnud. (TÜKK, aja 1970)

Elusat TAHTJAT võib tinglikult näha ka vanale kirjakeelele tüüpilistes konstruktsioonides, kus agendiks on jumal, nt

(16) .. eth se keycke wegkewe Jumal selle pattusel Ilmal tachtis üdden otzan tehe/ Nynck sen wymesen peywe kaes eb tachtis kauwa otada (VAKK, Wanradt-Koell 1535) 'et see kõigevägevam jumal sellele patusele ilmale tahtis lõpu teha ja viimsepäevaga ei tahtnud kaua oodata'

Tinglikult on elusa TAHTJANA tõlgendatavad agendina tegutsevad muinasjututegelased, organisatsioonid-kollektiivid ja loomad, nt 
(17) „Mina ei taha Limonaadihiir olla,“ piiksus hiireõde. (TÜKK, ilu 1990)

(18) Ja loomulikult tuleb ette näidata, mida auväärt komisjon näha tahab. (TÜKK, aja 1980)

(19) Hobune oli ka kõik selle päewa ree ees külmetanud, ei tahtnud wanale mehele aega anda peale istuda. (TÜKK, ilu 1890)

Üksikjuhtumitel on „soovijaks“ ka elutu objekt, mis on lauses personifitseeritud, $\mathrm{nt}$

(20) Kõik need uued seadused teeniwad üht eesmärki - tahawad türgi rahwast moderniseerida selle sõna laiemas mõttes. (TÜKK, aja 1930)

(21) See on elulõik, millel tema mõtted ei taha peatuda. (TÜKK, ilu 1970)

Tahetava sündmuse aktiivseimaks osaliseks on kõigil juhtudel samuti agent ise. Mõnel juhul on raske otsustada, kas pidada $d a$-infinitiivi veel verbi muutevormiks või on see niivõrd leksikaliseerunud, et seda tuleks pidada pigem käändsõnalise objekti sarnaseks, nt

(22) Kui ma näljasena magama lähen, siis ärkan öösel üles ja tahan süüa. (TÜKK, ilu 1970)

Koos kõnelemisverbidega esineb tahtma sageli retoorilise vormeli osana, olles kaotanud suure osa oma leksikaalsest sisust, nt

(23) Eraldi kiidusõnad tahan lausuda raamatukese kujundajale, Aare Haugile (TÜKK, aja 1990)

da-infinitiivis objektiga tahtma-soovlauseid esines 1890 . aastate valikkorpuses $76(31 \%), 1930$. aastate korpuses 99 (46\%), 1970. aastate korpuses 89 (44\%) ning 1990. aastate korpuses 83 (45\%). (Lisanduvad juhtumid, kus analoogse struktuuriga konstruktsioonis soovi ja kavatsuse tähendus ei eristu, vt jaotis 3.2). 
3.1.3. Latiivsed tahtekonstruktsioonid: TAHTJA (nominatiiv) + tahtma (vormipiiranguid ei ole) + SIHTKOHT (latiivne adverbiaal)

Eelmise konstruktsiooni erandjuhtumina esineb 20. sajandi II poole kirjakeele korpustes lauseid, kus eeldatav $d a$-infinitiivis liikumisverb on lausest välja jäetud ning soovi sihtkohta jõuda/liikuda väljendab tahtma-verb koos seda laiendava latiivse määrusega, nt

(24) Mulle siin ei meeldi. Tahan akna juurde. (TÜKK, ilu 1970)

(25) Tahtsin koju ja sauna. (TÜKK, aja 1990)

Ka niisugune konstruktsioon võib esineda mõnel juhul ülekandelises tähenduses, elutu ,soovijaga“, nt

(26) ILU1970lilu0035 Kenad luitunud jumega saomemmed, vakka ja mõttes, ootavad hangujaid, tahavad koju? (TÜKK, ilu 1970)

Latiivse määrusega tahtma-konstruktsioone esines valikkorpustes suhteliselt vähe: 1970. aastatel viis näidet (2\%) ja 1990. aastatel üks näide (1\%).

\subsubsection{Et-komplementlauset sisaldavad tahtekonstruktsi-}

oonid: TAHTJA (nom) + tahtma (vormipiiranguid ei ole) +

TAHETAV (et-lause)

$d a$-infinitiivikonstruktsiooni abil väljendatud soovitav sündmus või olukord eeldab tahtma-lausete puhul alati, et selle sündmuse agent või aktiivseim osaline on TAHTJA ise. Niisuguste soovide väljendamist, kus tahetava sündmuse agendiks on keegi teine kui kõneleja, võimaldab konstruktsioon, milles soovitavat sündmust väljendatakse $e t$-komplementlause abil.

Vanas kirjakeeles on tahtma-konstruktsiooniga esinevad etsihitislaused üsna haruldased, leidub vaid üksikuid selliseid näiteid: 
(27) Ke tahhab/ et keik Innimessed peawad önsax sama/ ja Töetundmissele tullema. (VAKK, UT 1715)

20. sajandil leidub niisuguseid kasutusi mõnevõrra rohkem, nt

(28) Ta pole tulnud siia Liigustele üksnes vananema ega oma aega viitma, ta tahab, et tema esimesest koolist tuleksid välja tõelised tulekandjad, need, kes süütavad leegi seal, kuhu nad lähevad. TÜKK, ilu 1970)

(29) No suu vajus lopsti kinni, ei osanud teine muud midagi, kui et eesti rahvas tahab, et teie istute - jah, sihuke oli ta vastus. (TÜKK, ilu 1930)

Kõrvallause verb on enamasti konditsionaalis, ent võimalik on ka verbi indikatiivivorm (vt näited 28 ja 29).

1890. aastate valikkorpuses esines et-komplementlausega tahtma-soovkonstruktsioon 3 korral (1\%), 1930. aastate korpuses 12 korral (6\%), 1970. aastate korpuses 7 korral (3\%) ning 1990. aastate korpuses samuti 7 korral (4\%).

\subsection{Agendi kavatsust väljendavad konstruktsioonid:}

KAVATSEJA (nominatiiv) + tahtma (vormipiiranguid ei ole)

+ KAVATSETAV ( $d a$-infinitiiv)

Osalejasisest võimalikkust väljendavad $d a$-infinitiivis objektiga tahtma-soovlaused on edasises arengus omandanud lisaks soovi tähendusele ka kavatsuse tähenduse, kusjuures osal kasutusjuhtudel võibki pidada lauses primaarseks kavatsuse tähendust (näide 30), aga sageli ei ole kavatsuse ja soovi tähendus teineteisest eristatavad (näide 31), nt

(30) Kogu ta olek andis mõista, et ta ei kavatse norimisele norimisega vastata, et ta tuli siia rahumeelsete mõtetega ega taha lahkudagi teistsugustega. (TÜKK, ilu 1970)

(31) „Nojah,“ nõustus Priit, kes tahtis Pauli vastu leplik olla ning kõik tema targutamised ära taluda. (TÜKK, ilu 1990) 
Agendikeskse kavatsuse väljendamise kohta leidub hulgaliselt näiteid juba vanast kirjakeelest, nt

(32) Nemmad jubba julged kostsid, et perremees tahhab homme isse sedda tööd hakkada. (VAKK, Willmann 1782) 'Nemad juba julgena vastasid, et peremees tahab homme ise seda tööd alustada.'

Konstruktsioon on struktuurilt väga sarnane soovi väljendava $d a$-infinitiivis objekti sisaldava konstruktsiooniga, samasugused on ka selle laiendused personifitseerituna käsitatud elututele subjektidele, retoorilised kasutused jm, nt

(33) Looduse jõud oliwad nagu wangist wallale peasenud ja nagu tahaksiwad nad ise oma tööd ära häwitada. (TÜKK, ilu 1890)

(34) Selle asemel tahab aga wähjatõbi, mis kalli „Linda“ Meremeeste Seltsi hauda wiis, nüüd Eesti waldade küljes jõudsalt sigineda, kibedaks südame waluks kõigile neile, kes rahwa hääd käekäiku südame all kannawad. (TÜKK, aja 1890)

Domineeriva kavatsusetõlgendusega lauseid esines 1890. aastate valikkorpuses $62(25 \%), 1930$. aastate korpuses 20 (9\%), 1970. aastate korpuses 28 (14\%) ja 1990. aastate korpuses 17 (9\%).

Neid näiteid, kus soovi ja kavatsuse tähendust eristada ei õnnestunud, oli 1890. aastate korpuses 83 (34\%), 1930. aastate korpuses 61 (29\%), 1970. aastate korpuses 44 (21\%) ning 1990. aastate korpuses 46 (25\%).

Kokkuvõtliku ülevaate tahtma-konstruktsioonide esinemusest statistilises valikkorpuses annab järgnev tabel. ${ }^{3}$

Nagu tabelist ilmneb, on tahtma-verbi sagedasim kasutuskontekst niisugune, kus tahtma-verb ise väljendab soovi ning soovitav „objekt“ on $d a$-infinitiivitarindi abil vormistatud sünd-

\footnotetext{
${ }^{3}$ Kuna modaalsete ja postmodaalsete kasutuste osakaal korpustes oli väga väike, ei ole nende kohta statistilisi andmeid eraldi välja toodud.
} 
mus, mille tegevussubjektiks on TAHTJA ise. Peaaegu sama suure osakaaluga on analoogse struktuuriga laused, kus soovi ja kavatsuse tähendust on keeruline eristada (1890. aastate korpuses on selliseid lauseid $d a$-infinitiivitarindiga tahtma-soovlausetest isegi pisut rohkem). Verbi tahtma grammatiseerunumad kasutused (modaalsed ja postmodaalsed, tabelis koondnimetuse „Muud“ all) esinevad korpustes üksnes marginaalse sagedusega.

Tabel. Tahtma-konstruktsioonide esinemissagedus valikkorpuses

\begin{tabular}{|l|l|l|l|l|r|}
\hline Konstruktsioon & 1890ndad & 1930ndad & 1970ndad & 1990ndad & KOKKU \\
\hline $\begin{array}{l}\text { SOOV }+ \\
\text { grammatiline } \\
\text { objekt }\end{array}$ & $11(5 \%)$ & $15(7 \%)$ & $27(13 \%)$ & $24(13 \%)$ & $\mathbf{7 7}$ \\
\hline SOOV + $d a-$ inf & $76(31 \%)$ & $99(46 \%)$ & $89(44 \%)$ & $83(45 \%)$ & $\mathbf{3 4 7}$ \\
\hline SOOV + latiiv & & & $5(2 \%)$ & $1(1 \%)$ & $\mathbf{6}$ \\
\hline $\begin{array}{l}\text { SOOV + } \\
\text { et- lause }\end{array}$ & $3(1 \%)$ & $12(6 \%)$ & $7(3 \%)$ & $7(4 \%)$ & $\mathbf{2 9}$ \\
\hline $\begin{array}{l}\text { KAVATSUS + } \\
\text { da- inf }\end{array}$ & $62(25 \%)$ & $20(9 \%)$ & $28(14 \%)$ & $17(9 \%)$ & $\mathbf{1 2 7}$ \\
\hline $\begin{array}{l}\text { KAVATSUS/ } \\
\text { SOOV + } d a-\text { inf }\end{array}$ & $83(34 \%)$ & $61(29 \%)$ & $44(21 \%)$ & $46(25 \%)$ & $\mathbf{2 3 4}$ \\
\hline Muud & $9(4 \%)$ & $6(3 \%)$ & $7(3 \%)$ & $5(3 \%)$ & $\mathbf{2 7}$ \\
\hline KOKKU & $\mathbf{2 4 4 ( 1 0 0 \% )}$ & $\mathbf{2 1 3 ( 1 0 0 \% )}$ & $\mathbf{2 0 7}(\mathbf{1 0 0} \%)$ & $\mathbf{1 8 3 ( 1 0 0 \% )}$ & $\mathbf{8 4 7}$ \\
\hline
\end{tabular}

\section{Verbi tahtma modaaltähendused}

Eelmises osas esitatud näidetes on enamasti väljendatud agendi enda tahet, st kas kõneleja või see, kelle kohta midagi väidetakse, on ise ühtlasi tahte allikas (v.a näide 8). Järgnevalt vaatame selliseid näiteid, kus tahtma-verbi kasutust motiveerib mingi võimalik takistus tahte ja verbi infinitiivse vormiga väljendatud tegevuse toimumise vahel. Tegevuse, millele tahe on suunatud (TAHETAV), ja agendi tahte vahel on niisugustes näidetes tajutav teatav konflikt. Allpool eristame modaaltähendusi ja tähendustevahelisi üleminekualasid selle alusel, kas agendi tahte ja modaalsuse elutu osaleja vahel esinev konflikt lähtub pigem kõneleja hinnangust elutu osaleja omadustele (dünaamiline $=$ osalejasisene/-väline võimalikkus) või on see pigem järeldus terviksi- 
tuatsioonist ja kontekstist (episteemiline vajalikkus). Modaaltähenduste eristamisel lähtume ühelt poolt materjalist enesest, teisalt on taustaks Auwera ja Plungiani arusaam modaaltähenduste kujunemisest ja jagunemisest (Auwera ja Plungian 1998, vt ka jaotis 1.1).

4.1. Osalejasisene võimalikkus: tahtma (vormipiiranguid ei ole) + verb (da-infinitiiv)

Osalejasisese võimalikkuse konstruktsioon on siin käsitletud modaalkonstruktsioonidest kõige madalamal grammatisatsiooniastmel, sest semantikas on läbinähtav seos verbi algse soovimistähendusega ning vormiliselt kasutab konstruktsioon $d a$-infinitiivis põhiverbi, mis on oma funktsioonilt lähedane tahtma-verbi objektilisele kasutusele (vrd tahan kooki > tahan sü̈̈ > tahan mõelda; vt ka jaotis 3.1.2). Vormipiiranguid tahtma-verbil selles konstruktsioonis pole. Modaaltähendus on ilmselt reanalüüsitud $d a$-infinitiivis objektiga konstruktsioonist (TAHTJA (nominatiiv) + tahtma (vormipiiranguid ei ole) + TAHETAV ( $d a$-infinitiiv)), nii et kujuneb hajus üleminekuala kahe tüübi vahel ning konstruktsioon hakkab grammatiseeruma.

Konstruktsiooni edasiarenguna võib käsitleda selliseid kasutusjuhtumeid, kus kõneleja annab hinnangu elutu osaleja „võimetele“. Need on iseloomulikud modaalsuse klassikalist definitsiooni illustreerivad näited. Modaalsust on käsitletud universaalse grammatilise kategooriana, mis on seotud sündmust kirjeldava propositsiooni staatusega kõneleja teadvuses (Palmer 2001: 1), kusjuures modaalsus hõlmab propositsiooni seda osa, mille abil kõneleja väljendab oma arvamust öeldava kohta. Modaalsus on seega kategooria, mis väljendab kõneleja suhtumiste grammatiseerumist. Niisiis näeme siin tahtma-verbi kasutusmotiivi selles, et see võimaldab anda hinnangu elutu osaleja käitumisele/tegevusele, lähtudes teatavast ülekandest selle „võimetele“.

Personifitseerimine kui tähendusülekanne loob kujundlikkuse skaalal selle astme, mille kaudu tahtma-verbi konstruktsioonidesse on sisenenud elutud osalejad, kellele ülekandeliselt omistatakse elus agendi tahe (vt ka jaotis 1.1). Järgnevate näitelausete 
tõlgendus on sellisel juhul kahetine: olukorda võib tajuda nii, et rattale (näide 35) või pulgakesele (näide 36) omistataksegi tahe iseseisvalt toimida, kuigi esilduv tõlgendus sisaldab pigem kõneleja hinnangut olukorrale üldisemalt, st episteemilist modaalsust, nt

(35) ma just eelmine aasta sõitsin talvel kõvakahvliga veel. ja noh lume peal hakkas lenks suht vastikult tantsima ja ratas tahtis pidevalt oma teed minna ja tunne oli väga ebastabiilne. (TÜKK, UM)

(36) Minul oli seal selline probleem, et see pulgake, mis peaks siis sisemist ja välimist muhvi läbistama ja roolikeeramise võimalikuks tegama, tahtis hoopis august „välja kukkuda." (TÜKK, UM)

Sarnaseid näiteid leidub ka vanas kirjakeeles:

(37) Siis on se sü teie polest, sest et Jummala sanna paistab ja tahhab teid walgustada .. (VAKK, Helle 1732)

Ühtlasi selgub neist näidetest, et tingimusi, millest tegevus sõltub, on raske hinnata ainult elutust osalejast või olukorrast tingitud välistest omadustest sõltuvaks (nt Auwera ja Plungiani modaalsuse kaardi alusel (1998: 82)). Sellised kontekstid näitavad kõige paremini üleminekuala episteemilistele ehk kogu propositsiooni tõelevastavust hõlmavatele modaaltähendustele.

\subsection{Osalejaväline vajalikkus (netsessiiv): tahtma} (3SG/PL) + verb (da-infinitiiv või mine-teonimi)

EKG järgi (II: 186) sisaldub tahtma tähenduses deontilise e kohustuslikkusmodaalsuse komponent, näitena on toodud Põrandad tahavad värvida. Reanalüüsi võimaldava konteksti näitena võiks kasutada lauset

(38) Koer tahab jalutada. 
Eelnevat lauset on võimalik tõlgendada kas koera kui elusolendi soovi edastamisena kõneleja vahendusel (osalejasisene võimalikkus) või osalejavälise vajalikkuse rõhutamisena, st väljendatakse umbisikulise agendi kohustust koer jalutama viia.

Näiteid, milles tahtma väljendab vajalikkust või paratamatust, leiame nii tänapäeva eesti keelest (näide 39) kui ka vanast kirjakeelest (näide 40).

(39) Kuid samal ajal ei jõudnud vanaemad vastata Venemaalt saabuvatele küllakutsetele, rääkimata sõitmisest. Sest kartul tahtis panna ja aed harida. (http://www.epl.ee/artikkel/ 493664.)

(40) Kui köhha neile tulleb tolmosest toidust, siis tahhab sesuggune toit, nenda kui muidogi ikka peaks sündima, enne kui ette antakse weel surema holega läbbipeksta ja puistada. (VAKK, Knüpffer 1837)

tahtma-konstruktsioonid, mis on lähtunud ilmselt elutu osalejaga $d a$-infinitiivsetest tahtekonstruktsioonidest, võimaldavad väljendada ka propositsiooniga seotud üldisikulist kohustust. Sellistes loomulikes rahvakeelsetes lausetes on ilmselt tegemist reanalüüsiga tahtelise agendi tegevuselt mittetahtelisele osalejale. Kohustusliku tegevuse sooritajaks on sellisel juhul määratlemata elus tegija.

$d a$-infinitiivi kõrval on tegevust, millele tahe on suunatud, väljendatud tänapäeva eesti keeles ka mine-teonimega (näide 42). Ka seda tüüpi konstruktsioonid väljendavad passiveeritud kohustuslikkust või vajalikkust: tegevuse agent on konstruktsioonis määratlemata. Võimalik, et sellisel juhul on tegemist ka teatava viisakusstrateegiaga, mis võimaldab kohustust väljendada nii, et seda ei seota käsuna ühegi konkreetse tegijaga, kuigi järeldusena on tegevuse sooritamise vajalikkus ilmne, nt

\section{(41) Lapsed tahavad õpetamist ja juhatamist.}

Eesti vanas kirjakeeles leidub selliseid näiteid harva. On selge, et need ei kuulu tollasesse kirikukeele stiili ning on ilmselt rahvakeelsed, nt 
(42) Woi siis nenda sunneti neid öppima kui nüüd? ja meie suggu rahwas tahhab sundimist. (VAKK, Helle 1732)

Keeles leidub konstruktsioone, kus agendiks sobiva subjekti korral jätab $d a$-infinitiivis põhiverb võimaluse tõlgendada taht$m a$-verbi 'soovi' tähenduses, st konstruktsioonil puudub ilma kontekstita ühene tõlgendus, grammatiline subjekt võib markeerida nii agenti kui ka patsienti (näited 43, 44). Niisiis on patsiendi-tõlgenduse korral tegemist passiivse konstruktsiooniga, nt

(43) Laps tahab pesta. (osalejasisene soov või osalejaväline vajalikkus)

(44) Laps tahab pesta. Laps tahab pesemist. (osalejaväline vajalikkus)

Elutu patsiendi korral kahemõttelisust ei teki ning sel juhul on mine- ja $d a$-konstruktsioon ilmselt sünonüümsed, nt

(45) Pott tahab pesta. Pott tahab pesemist.

Konstruktsiooni vormile on iseloomulik see, et verb võib arvus ühilduda elutu osalejaga, nt

(46) Mitu kohvritäit märgi dokumente tahavad läbivaatamist.

(Aktuaalne Kaamera 18.03.2010)

tahtma-verbi elutule tegevussubjektile (näide 47, auto) või agendina vormistatud elus osaleja võõrandamatule omandile (näide 48 käed) saab selle elus omaniku lisada adessiivse argumendiga, nt

(47) Mul tahab auto parandada/parandamist.

(48) Sul tahavad käed pesta/pesemist!

Selline osalejate vormistus avaldub ka teistes osa-terviku, omandi, valduse vms suhteid väljendavates konstruktsioonides, nt possessiivse perfekti konstruktsioonis (vt Lindström ja Tragel 
2007). Nii vormistatud osalejat on nimetatud ka väliseks omajaks (ingl external possessor, vt nt Haspelmath 1999).

\subsection{Episteemiline modaalsus}

\subsubsection{Episteemiline vajalikkus tahtma (3SG/PL) + verb (da-infinitiiv)}

Eesti vanas kirjakeeles leidub tahtma-konstruktsioonide episteemilisi kasutusjuhtumeid, mis sisaldavad tõeväärtushinnangut kogu lausesisule (näited 49, 50). Ülekandelisele kasutusele elutut objekti kui tahtjat nimetavas konstruktsioonis (näide 49) on järgnenud võimalus väljendada sellise konstruktsiooni abil lausesisu tõenäosust. Tegemist ei ole enam tahtelise agendi tegevusega, mistõttu verbi tähenduses ja konstruktsiooni funktsiooni laienemises toimunud nihe võimaldab väljendada modaalhinnangut kogu lausesisule (näide 50, vt ka jaotis 1.1).

(49) Kui ühtegi ei tahha aitada siis aitab se rohhi mis ma praego tahhan nimmetada .. (VAKK, Hupel 1771) 'Kui miski ei taha aidata, siis aitab see rohi, mida ma praegu tahan nimetada.'

(50) Ei middagi, need on södikud waimud, kus neid paljo sünnib, se tahhab nuhtlus olla (VAKK, Helle 1732).

Seda tüüpi rahvapäraseid episteemilise kasutuse näiteid leidub veel ka 19. sajandi tekstides, nt

(51) Se on siis suureks kassuks, kui tullokse juhtub lahtipeäsema, sest et muido ennamiste ei tahha lambaid koggoni tallist wälja sada. (VAKK, Knüpffer 1837)

Tänapäeva keelekasutuseski võib leida sellise modaaltähenduse näiteid:

(52) Koerad tahavad kasvada - palke ja hobust saab raha eest, kui seda jätkub. (TÜKK, ilu 1970) 
4.3.2. Õnnestumismodaalsus: tahtma (3SG/PL) + verb (da-infinitiiv)

Episteemilis-modaalsete konstruktsioonide hulka võiksid kuuluda ka (eba)õnnestumiskonstruktsioonid, mis samuti hõlmavad propositsiooni tervikuna ning kujutavad konstruktsiooniliselt arvatavasti osalejasisese võimalikkusmodaalsuse edasiarengut. Konstruktsiooni põhitähenduseks on 'ebaõnnestumine' ja taht$m a$-abiverb on sellises konstruktsioonis alati 3. pöörde vormis (nii ainsuses kui ka mitmuses, nii olevikus kui ka minevikus). Iseloomulik on selle konstruktsiooni eituslembesus, st tahtma on siin kasutusel eitavas kõnes (näited 53, 54).

(53) Ai-vai, neil ei tahtnud täna kuidagi vedada. (TÜKK, ilu 1930)

(54) Koostöö toimib, kuid ühinemine ei taha edeneda. (http:// paber.maaleht.ee $/$ ?page $=28062 \&$ grupp $=$ maamajandus $\&$ arti kkel=9)

Õnnestumismodaalsuse konstruktsioonilist seost osalejasisese võimalikkuse konstruktsiooniga osutab ülekandetüüp (personifikatsioon) ja konstruktsioonide sarnane vorm (näide 55; vrd jaotis 4.1, näited 35 ja 36).

(55) Saabas ei taha jalga minna.

Eelneva lausega edastatud sündmus pole tõlgendatav „tahtelise" saapa kesksena, vaid pigem agendi hinnanguna olukorra õnnestumisele/ebaõnnestumisele, kus ülekandeliselt tematiseeritakse elutu osaleja roll ning implitsiitselt on taustal ka elus tegija.

\section{Tulevik: tahtma (vormipiiranguid pole) + verb (da-infinitiiv)}

Omaette kategooriana väärib ka eesti kirjakeele kontekstis käsitlemist tahtma-tulevik. Tüpoloogilistes käsitlustes kirjeldatakse 
seda sageli osalejakeskse modaalsuse edasiarendusena, mis on grammatisatsiooniprotsessis episteemilise modaalsuse lähtevaldkonnaks (vt nt Heine ja Kuteva 2002: 142-143). Seda näib tõendavat ka eesti keele konstruktsiooni vorm ja üldine 'ennustust' osutav tähendus.

Näiteid tuleviku väljendamisest tahtma-konstruktsiooni abil leidub juba 16. sajandi tekstides (näide 56), kuid selgemad on seda tüüpi näited 17. sajandi alguse saksamõjulistes tekstides (näide 57).

(56) [ninck s]eperest Jumal tahap o[mahe]nd owespette neys kahes [sidde]s/ ses hiwus nynck ses [weres]/ laske kynny köwteda .. (VAKK, Wanradt-Koell 1535) 'Ning seepärast tahab Jumal end väliselt nendes kahes, ihus ja veres, kinnitada lasta.'

(57) Ninck mina taha, spricht der Herr, üx tulline Mühr ümber teidt olla, nick tahan seel siddes olla, ninck tahan hend auwsasti sæl sid: neuta .. (VAKK, Müller 1604) 'Ning mina tahan, ütleb Jumal, üks tuline müür teie ümber olla, ning tahan seal sees olla ning tahan end seal sees ausasti näidata.'

Kuigi esimese eestikeelse täispiibli väljaandmisele (1739) eelnes põhjalikke keelearutelusid ja lepiti kokku mõningates rahvakeelelähedastes põhimõtetes, jäi tahtma-futuurumi konstruktsioone selleski teoses kasutusele. Ilmselt on tegemist seda tüüpi üksikute kasutusjuhtudega, mille esinemine kanoonilises tekstis tundus loomulik ja mida ei peetud vajalikuks teadlikult vältida, nt

(58) Sepärrast tahhan ma nüüd teile täetada sedda, mis ma omma winamäele tahhan tehha. Ma tahhan temma aeda mahhakiskuda, et tedda peab paljaks ärrasödama, ma tahhan ta kiwwiaeda mahhakiskuda, et tedda peab ärrasötkutama. (VAKK, Piibel 1739).

Üksikuid tahtma-tuleviku näiteid leidub veel ka 19. sajandi tekstides, nt 
(59) Ma tahhan ommiko warra wõidu sõnu teile lausuda, mis ühhe kuulsa Allotagguse targa suust õppisin .. (VAKK, Kreutzwald 1850)

Niisugust kaugele grammatiseerunud futuurumivormi kasutust, nagu näeme inglise ja saksa keeles (will ja wollen - algne tähendus 'tahtma', praegu muuhulgas tuleviku abiverbid), ei ole eesti tahtma-verbil aga tekkinud, kuigi vanast kirjakeelest leiab hulgaliselt näiteid tahtma-verbi tulevikule osutavate konstruktsioonide kohta (Habicht 2001: 165-166, 170-173), mille kasutuses võib näha selget tõlkemõju:

(60) Minna tahan sedda tegkema/ minna tahan töstma/ kandma/ ninck errapehstma/ minna tahan teid röhmustama/ kudt öhe Lapse se Emma tröhstip/ Jch wil es thun/ ich wil heben/ tragen vnd erretten/ Jch wil euch trösten/ wie einen seine Mutter tröstet/ (VAKK, Stahl 1641) 'Mina tahan seda teha, mina tahan tõsta, kanda ja ära päästa, mina tahan teid rõõmustada, nagu ema trööstib last.'

Tänapäeva eesti keeles tahtma-verbiga tulevikukonstruktsioone ei leidu, selle funktsiooni on enda kanda võtnud põhiliselt saama-verb, mis on tulevikukonstruktsioonide vormistajana saanud samuti tugevaid mõjutusi saksa keelest. tahtma-futuurumi taandumisele võib olla kaasa aidanud see, et seda kui saamakonstruktsiooniga võrreldes tunduvalt harvem kasutatud ja võõrapäraseks peetud futuurumikonstruktsiooni on teadliku keelekorraldustöö käigus olnud lihtsam kirjakeelest tõrjuda. Teiseks põhjuseks võib olla eelmisega seotud sageduskriteeriumist tulenev funktsionaalse liiasuse vältimise taotlus: väiksema sagedusega grammatiline konstruktsioon on taandunud sama funktsiooniga sagedasema saama-konstruktsiooni ees. Vana kirjakeele perioodil esinenud tahtma-tuleviku konstruktsioone võib niisiis pidada kontaktimõjulise grammatilise kopeerimise (replication) näiteks (vt Heine ja Kuteva 2006: 63). 


\section{Postmodaalsed tähendused}

\subsection{Avertiiv ja proksimatiiv: tahtma (3SG/PL) + verb (da-infinitiiv)}

Siinses käsitluses vaadeldakse verbi aspektikategooria alla kuuluva avertiivi ja proksimatiivi tähendust koos, sest oleme seisukohal, et nende selgemaks eristamiseks oleks vaja teha tõlgendamiskatseid keelekasutajate hulgas. Praeguse materjali põhjal tundub, et eesti keeles on enamik seda tüüpi näiteid siiski pigem avertiivsed, st nende tõlgendamisel on oluline aspekt verbisündmuse 'peaaegu' toimumine, tegevuse vältimise soov ning selle tegelik toimumata jäämine (vt Kuteva 1999: 36).

Tüpoloogilistes uurimustes on kirjeldatud tendentsi, mille kohaselt avertiiv võib areneda proksimatiiviks (Kuteva 1998). Mati Erelt nimetab avertiivi ja proksimatiivi sama kategooria (prospektiivi) allkategooriateks: proksimatiiv on sellisel juhul markeerimata ja avertiiv markeeritud prospektiiv (Erelt 2009). Proksimatiiv on aspektitähendus, mis osutab verbisündmuse eelfaasile ehk faasile, mis paikneb põhiverbiga edastatud sündmuse alguspiiri lähedal (tähendusnüanss 'peatsus'). Kuteva sõnul on proksimatiivi sisuks eelfaasile viitamine, ehkki see aspektitähendus ei anna teavet sündmuse toimumise aja ega selle kohta, kas sündmus üleüldse toimus. (Kuteva 1998)

Eesti keele proksimatiivse aspekti avaldumist on uurinud Mati Erelt ja Helle Metslang, kes illustreerivad seda tüüpnäitega (61), väites ühtlasi, et seda tüüpi näite puhul on olemas potentsiaalne võimalus verbisündmuse toimumiseks (näide 62):

(61) Puder tahab põhja kõrbeda

(62) Puder tahtis põhja kõrbeda ja kõrbeski. (Erelt ja Metslang 2009: 178)

Avertiivile ja proksimatiivile on ühine tähendusnüanss 'peatsus' ehk 'imminentsus', mis omakorda raskendab nende selget piiritlemist.

Enne tegeliku kasutuse uurimist ei ole ole võimalik midagi kindlat väita, kuid tundub, et sündmuse tõsikindla (ja soovitud) 
toimumise väljendamiseks valitaks ilmselt muud keelevahendid kui tahtma-konstruktsioon. Eespool toodud lause 62 on küll grammatiliselt korrektne, kuid pragmaatiliselt selles tähenduses kaheldav (liiane). Lause 61 saaks sellest lähtuvalt pigem avertiivse tõlgenduse, sest väljendab sündmust, mida soovitakse vältida ja sellise väljenduse korral tõenäoliselt välditaksegi, st sündmus, mis on peaaegu toimumas, tegelikult ei toimu.

See, et ühe eristuva postmodaalse tähendusena on tahtmakonstruktsioonidel välja arenenud avertiivi tähendus, lähtub ilmselt tähendusülekandest, mille käigus elutule osalejale kantakse üle elus agendi omadused. See tähendab tegelikkuses aga propositsiooni tõeväärtushinnangust lähtunud edasitõlgendust. Lisanduv tähenduskomponent on sündmuse hindamine 'peaaegu' toimuvaks/toimunuks. Teine oluline avertiivset tõlgendust võimaldav tähendusfaktor on 'takistus', mis on iseloomulik ka modaalsetele tahtma-konstruktsioonidele.

Eesti keeles on avertiivsust võimalik väljendada eeskätt $p i-$ dama-verbi imperfekti vormiga pidi ja ma-infinitiivis põhiverbiga konstruktsiooni abil. Sellist kasutust on täpsemalt kirjeldanud Mati Erelt (2001), nt

(63) Jüri pidi üllatusest pikali kukkuma.

(64) .. laev pidi nende raskuse all põhja minema. (Erelt 2001: 23)

Avertiivne tähendus ei sisalda tahtelist komponenti, seetõttu tulebki see selgemalt välja just siis, kui infinitiiviks on seisundit või mittetahtelist protsessi väljendav verb. Verbi pidama avertiivne tähendus väidetakse olevat ainult minevikuvormil, olevikuvorm on sarnase vormiga konstruktsioonis tõlgendatav pigem deontilisena: Jüri peab üllatusest pikali kukkuma ('on kohustatud pikali kukkuma'). tahtma-konstruktsioonide puhul see vormiline seaduspärasus ilmselt siiski ei kehti: vrd Jüri tahtis naerust nõrkeda. Jüri tahab naerust nõrkeda. Vormi valik sõltub siin pigem kõneleja valitud ajalisest vaatepunktist.

Vanemas kirjakeeles leidub avertiivsuse/proksimatiivsuse näiteid väga harva. Et selline kasutus on siiski vanemas rahvakeeles olemas olnud, osutab F. J. Wiedemanni eesti-saksa sõnaraamat, kus esitatud näidet 65 on võimalik nii tõlgendada. 
(65) tahab kui uskmata näidata 'es ist, scheint, beinahe unglaublich' (Wiedemann 1973 [1893]: 1110) 'see näib peaaegu uskumatu'

Avertiivsena võiks tõlgendada ka järgmisi 19. sajandist pärit tekstinäiteid:

(66) Kui hobbone ommas ihhus laisaks ehk raskeks jääb; ehk kül wäljaspool middagi nähha ep olle, siis ommeti ratsa söites ehk wankri ees peagi nähha, et warsi ärra tahhab wässida .. (VAKK, Freundlich 1849)

(67) .. et külm seal kartohwlites wõõrsil käinud, mis pärast kewadel seemne puudus kätte tahtwat tulla. (TÜKK, aja 1890)

Tänapäeva kirjakeeles ei ole avertiivsus küll tahtma-konstruktsioonide sagedane grammatiline tähendus, kuid see on siiski säilinud, nt

(68) Vedel maa tahtis inimest tervenisti oma pimedasse põue neelata. (TÜKK, ilu 1970)

Siin on tõlgenduses oluline tähenduskomponent just 'peaaegu' ja maailmateadmisele tuginev lisatähendus, et tegevus sellisena siiski ei toimu.

Mida vähem on võimalik tahtma-verbi agendina vormistatud entiteedile tahet omistada (mida madalamal elusushierarhia astmel see on), seda suurema tõenäosusega võib kasutus saada avertiivse/proksimatiivse tõlgenduse, $\mathrm{nt}$

(69) Tulin tagasi ja laev tahtis ära uppuda .. kohe tekkisid vahepeal religioossed mõtted. (TÜKK, Delfi kommentaarid 2004)

Lihtminevikulistes konstruktsioonides on tahtma tähendusvarjund võrreldav pidi-avertiiviga (vrd ka Kell pidi seisma jääma, Pudel pidi maha kukkuma), nt 
(70) Kell tahtis seisma jääda.

(71) Pudel tahtis maha kukkuda.

\subsection{Habituaal: tahtma (3SG/PL) + verb (da-infinitiiv)}

Habituaalsuse (tavapärasuse) kui tegevust iseloomustava aspekti väljendamine on tahtma-konstruktsioonil välja arenenud postmodaalne tähendus, mille kohta ei leidu vanemas kirjakeeles siiski eriti palju näiteid. Et tegemist on rahvakeeles olemas olnud grammatilise tähendusega, osutab ühelt poolt see, et tähendus on välja toodud ka F. J. Wiedemanni eesti-saksa sõnaraamatus:

(72) tõbi ei taha muidu tulla 'die Seuche pflegt sonst nicht zu kommen' (Wiedemann 1973 [1893]: 1110) 'tõbi ei tavatse muidu tulla'

Teiseks tõenduseks on üksikud 19. sajandi tekstid, kus seda tähendust esineb, nt

(73) Agga ei olnud ilm teine, kui se muidogi selge küündla ku päwal tahhab seal mäggisel maal olla. (VAKK, Schüdlöffel 1843) 'Aga ei olnud ilm teistsugune, kui see selgel küünlakuu päeval tavatseb seal mägisel maal olla.'

Tänapäeva kirjakeeles see aspekt tahtma-konstruktsioonides enam ei avaldu.

\section{Kokkuvõtteks}

tahtma-verb on oma konstruktsioonilises arengus läbinud omapärase tee: täistähendusliku tahet ja soovi väljendava lekseemi baasil on arenenud soovimis-kavatsuskonstruktsioon, mille edasiarendusena võib näha saksamõjulise kirjakeele etapil kasutusel olnud tulevikukonstruktsiooni. Soovimis-kavatsuskonstruktsioonist on lähtunud ka võimalikkusmodaalsust, episteemi- 
list modaalsust ning viimasest omakorda avertiivsust/proksimatiivsust ja habituaalsust väljendavad postmodaalsed konstruktsioonid.

tahtma-verbi mittemodaalsed, vähem grammatilised kasutused on tekstides grammatilistest kasutustest oluliselt sagedasemad, iseäranis dominantne on tahtma-verbi kasutus soovi või soovi/kavatsust väljendavates konstruktsioonides koos $d a$-infinitiivis objektiga, mis väljendab soovitavat/kavatsetavat sündmust. Soovi (ent mitte kavatsust) väljendavates konstruktsioonides võib $d a$-infinitiivis objekti asemel esineda ka nimisõnaline objekt - selline konstruktsioon on ilmselt ajalooliselt vanim -, latiivne kohamäärus või et-komplementlause. tahtma-verbi grammatiseerunud kasutuste lähtekohaks on nähtavasti olnud soovimis-kavatsemiskonstruktsiooni metafoorsed laiendused elututele osalejatele.

Modaaltähendused on kujunenud ühelt poolt grammatisatsiooni üldtendentse arvestades ootuspäraselt, teisalt võib näha ka erilisi, tänapäevaks taandunud arenguteid (nt vana kirjakeele perioodil grammatilise kopeerimise tulemusel esinev tahtmafutuurum). Modaaltähenduste arengus saab selgelt eristada mittemodaalsetest soovimis-kavatsuskonstruktsioonidest lähtunud osalejasisese võimalikkuse ja osalejavälise vajalikkuse (netsessiiv-) konstruktsiooni ning nende edasiarendusena kujunenud episteemilis-modaalseid konstruktsioone, mille all on ühe eristuva allrühmana võimalik kirjeldada (eba)õnnestumiskonstruktsioone. Postmodaalsetest kasutustest tõuseb eriti esile avertiiv, mida siinses käsitluses ei ole lahutatud proksimatiivist, ja vanemas kirjakeeles esinev habituaal.

Skemaatiliselt võiks tahtma-verbi tähenduste arengut järjest suurema grammatilisuse suunas kujutada järgmiselt:

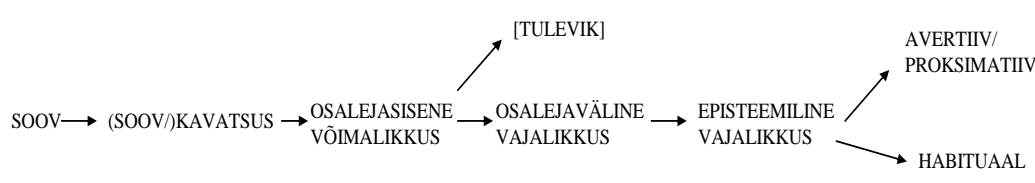

Vana kirjakeele tõlkemõjuliste religioossete tekstide perioodil toimus saksa keele eeskujuline „sundgrammatiseerumine“ ehk grammatiline kopeerimine, mille tulemuseks on saksa wol- 
len-futuumi eeskujulised tahtma-verbi sisaldavad tõlkevasted, mille abil väljendati tegevuse tulevikulisust. Hiljem on see üsna kaugele grammatiseerunud ajaline tähendus keeles taandunud. Loomulik keelesisene areng on aga viinud episteemilise modaalsuse tekkeni ja sealt edasi postmodaalsete tähendusteni.

Juba vanimates võõrmõjulistes kirjakeele allikates võib näha tahtma-verbi kuulumist põhiliselt infinitiivikonstruktsioonide koosseisu. Kõige sagedasem on selle esinemine agendikeskset soovi ja kavatsust väljendavates konstruktsioonides, millest grammatisatsiooniprotsess algab. Hulgaliselt on vanas kirjakeeles näiteid ka episteemilis-modaalsest ja saksamõjulisele wollenfutuurumile vastavast futuursest kasutusest.

Vastates lõpetuseks artikli pealkirjas esitatud küsimusele Kas tahtma tahab abiverbiks?, võib öelda, et tahtma-verb on oma tähenduste arengus läbinud juba mitu grammatiseerumise etappi ja seega on ta kindlates modaalsetes ja postmodaalsetes konstruktsioonides kujunenudki abiverbiks, ehkki ülekaalus on veel kontekstid, kus ta on säilitanud oma algse leksikaalse 'soovimise' tähenduse.

Külli Habicht, Pille Penjam, Ilona Tragel

Eesti ja üldkeeleteaduse instituut

Tartu Ülikool

Ülikooli 18

50090 Tartu

Kulli.Habicht@ut.ee

Pille.Penjam@ut.ee

Ilona.Tragel@ut.ee 


\section{Kirjandus}

van der Auwera, Johan, Vladimir Plungian (1998) "Modality’s semantic map". Linguistic Typology 2, 125-139.

Bybee jt 1994 = Bybee, Joan, Revere Perkins, William Pagliuca (1994) The evolution of grammar. Chicago: University of Chicago Press.

EKG II = Erelt, Mati, Reet Kasik, Helle Metslang, Henno Rajandi, Kristiina Ross, Henn Saari, Kaja Tael, Silvi Vare Eesti keele grammatika II. Süntaks. Lisa: kiri. Trükki toimetanud Mati Erelt (peatoimetajana), Tiiu Erelt, Henn Saari, Ülle Viks. Tallinn: Eesti Teaduste Akadeemia Keele ja Kirjanduse Instituut, (1993)

EKSS = Eesti keele seletav sõnaraamat. 5: S-T. „Eesti kirjakeele seletussõnaraamatu“ 2., täiendatud ja parandatud trükk. (2009) Margit Langemets, Mai Tiits, Tiia Valdre, Leidi Veskis, Ülle Viks, Piret Voll, toim. Tallinn: Eesti Keele Sihtasutus.

Erelt, Mati (2001) "Some notes on the grammaticalization of the verb pidama in Estonian”. Mati Erelt, toim. Estonian: Typological Studies V, 7-25. (Publications of the Department of Estonian of the University of Tartu 18.) Tartu: Tartu Ülikooli Kirjastus.

Erelt, Mati (2009) „Prospektiiv ja retrospektiiv eesti keeles“. Emakeele Seltsi aastaraamat 54 (2008), 44-53. Tallinn: Teaduste Akadeemia Kirjastus.

Erelt, Mati, Helle Metslang (2009) "Some notes on proximative and avertive in Estonian”. Linguistica Uralica XLV, 3, 178-191.

Habicht, Külli (2001) Eesti vanema kirjakeele leksikaalsest ja morfosüntaktilisest arengust ning Heinrich Stahli keele eripärast selle taustal. (Dissertationes philologiae estonicae universitatis tartuensis 10.) Tartu: Tartu Ülikooli Kirjastus.

Haspelmath, Martin (1999) "External possession in a European areal perspective". Doris L. Payne, Immanuel Barshi, toim. External Possession, 109-135. Amsterdam: John Benjamins.

Heine jt 1991 = Heine, Bernd, Ulrike Claudi, Friederike Hünnemeyer (1991) Grammaticalization. A conceptual framework. Chicago: University of Chicago Press.

Heine, Bernd, Tania Kuteva (2002) World lexicon of grammaticalization. Cambridge: Cambridge University Press.

Heine, Bernd, Tania Kuteva (2006). The changing languages of Europe. Oxford: Oxford University Press.

Heine, Bernd, Tania Kuteva (2007) The genesis of grammar. A reconstruction. Oxford: Oxford University Press. 
Hopper, Paul J., Elizabeth Closs Traugott (1993) Grammaticalization. (Cambridge Textbooks in Linguistics.) Cambridge: Cambridge University Press.

Häkkinen, Kaisa (2005). Nykysuomen etymologinen sanakirja. Juva: WS Bookwell Oy.

Kuteva, Tania (1998) "On identifying an evasive gram: action narrowly averted". Studies in Language 1, 113-160.

Kuteva, Tania (1999) "TAM-auxiliation, and the avertive category in Northeast Europe". Grammaticalization aréale et semantique cognitive: les langues fenniques et sames. Oural-Ural 1, 27-41. Tallinn: Eesti Keele Sihtasutus.

Kuteva, Tania (2001) Auxiliation. An enquiry into the nature of grammaticalization. Oxford: Oxford University Press.

Lindström, Liina, Ilona Tragel (2007) „Eesti keele impersonaali ja seisundipassiivi vahekorrast adessiivargumendi kasutamise põhjal“". Keel ja Kirjandus L, 7, 532-553.

Metslang, Helle (1994) „Eesti ja soome - futuurumita keeled?“ Keel ja Kirjandus XXXVII, 9-10, 534-547; 603-616.

Metslang, Helle (2002) „Grammatikalisatsiooniteooriast eesti keele taustal". Renate Pajusalu, Ilona Tragel, Tiit Hennoste, Haldur Õim, toim. Teoreetiline keeleteadus Eestis, 164-178. (Tartu Ülikooli üldkeeleteaduse õppetooli toimetised 4.) Tartu: Tartu Ülikooli Kirjastus.

Metslang, Helle (2006) „Grammatisatsiooniteooriast tänase pilguga“ Ilona Tragel, Haldur Õim, toim. Teoreetiline keeleteadus Eestis II, 176-195. (Tartu Ülikooli üldkeeleteaduse õppetooli toimetised 7.) Tartu: Tartu Ülikooli Kirjastus.

Mägiste, Julius (2000) Estnisches etymologisches Wörterbuch X. 2. Auflage. Helsinki: Finnisch-Ugrische Gesellschaft.

Palmer, F. R. (2001) Mood and Modality. 2nd edition. Cambridge: Cambridge University Press.

Penjam, Pille (2008) Eesti kirjakeele da- ja ma-infinitiiviga konstruktsioonid. (Dissertationes philologiae estonicae universitatis tartuensis 23.) Tartu: Tartu Ülikooli Kirjastus.

Tragel, Ilona (2003) Eesti keele tuumverbid. (Dissertationes linguisticae universitatis tartuensis 3.) Tartu: Tartu Ülikooli Kirjastus.

Traugott, Elizabeth Closs, Bernd Heine, toim (1991). Approaches to grammaticalization. Vol. I. Focus on theoretical and methodological issues. Amsterdam/Philadelphia: John Benjamins Publishing Company. 
Wiedemann, Ferdinand Johann (1973) [1893] Eesti-saksa sõnaraamat. Neljas, muutmata trükk teisest, Jakob Hurda redigeeritud väljaandest. Tallinn: Valgus.

Külli Habicht, Pille Penjam and Ilona Tragel. The Verb tahtma 'want' as an Auxiliary in Estonian? This paper gives an overview of the semantic and morphosyntactic development of the Estonian polysemous verb tahtma 'want' from $16^{\text {th }}$ century to nowadays. The data mainly comes from the corpus of written Estonian. The theoretical background of the paper is grammaticalization approach. The paper looks at the stages of development from the full lexical item to highly grammaticalized usages in modal and postmodal constructions.

Special attention is paid to the various types of infinitival constructions tahtma 'want' occurs in. The paper discusses the meaning and functions the verb tahtma has in these constructions. Tahtma may express volition, intention, participant-internal possibility, necessity, epistemic modality and postmodal meanings (e.g. avertive/proximative and habituality) in infinitival constructions. In Old Written Estonian (till $18^{\text {th }}$ century) there are constructions where tahtma is used to express future but these (as characteristic of Old Written Estonian) are influenced by German. tahtma does not express future in modern Estonian.

In conclusion the hypothetical grammaticalization path of tahtma is presented. tahtma is used as an auxiliary verb in certain constructions, although the possible original lexical meaning 'to wish' is present also in modern Estonian.

Keywords. Estonian verb tahtma 'want', grammaticalization, modal constructions 